\title{
Fas and Fas-mediated effects on a human salivary cell line in vitro: a model for immune-mediated exocrine damage in Sjögren's syndrome
}

\author{
Gallya Gannot ${ }^{1}$, Debbie Bermudez ${ }^{1}$, David Lillibridge ${ }^{1}$ and \\ Philip C. Fox ${ }^{1,2}$ \\ ${ }^{1}$ Clinical Investigations and Patient Care Branch, National Institute of Dental \\ Research, National Institutes of Health \\ 2 Corresponding author: Dr. Philip C Fox, NIH, NIDR, Building 10, Room \\ $1 \mathrm{~N}-113,10$ Center Drive MSC 1190, Bethesda, Maryland 20892-1190, USA. \\ Tel: 301-496-4278l; fax: 301-402-1228; e-mail pfox@yoda.nidr.nih.gov
}

Received 30 July 1997; revised 10 April 1998; accepted 8 May 1998 Edited by $D$ Green

\begin{abstract}
Sjögren's syndrome (SS) is an autoimmune exocrinopathy characterized by mononuclear cell infiltration and loss of parenchymal tissue in salivary and lacrimal glands. The mechanisms for these histologic alterations are not known. Apoptotic cell death, induced by the ligation of Fas (APO-1/ CD95) with Fas ligand (FasL/CD95L) may be an explanation for the tissue damage seen in SS. Fas and FasL were detected in minor salivary glands from SS patients and healthy individuals using immunohistochemical methods. There was increased expression of both Fas and FasL in the patients. The ability of the Fas-FasL pathway to influence epithelial cell growth and survival was demonstrated in vitro using a human submandibular cell line. The presence of Fas receptor was demonstrated on the cells. Anti-Fas antibody triggered cell death. Cells were also grown in the presence of gammainterferon (IFN- $\gamma$ ). IFN- $\gamma$ induced an upregulation of Fas receptor expression and pre-treatment of cells with IFN- $\gamma$ led to enhanced anti-Fas mediated cell death.
\end{abstract}

Keywords: Fas; salivary gland; apoptosis; exocrinopathy; Sjögrens syndrome

Abbreviations: SLE, systemic lupus erythematosus; SS, Sjögren's syndrome; EMEM, Eagle's minimal essential medium; PBS, phosphate buffered saline

\section{Introduction}

Fas (also termed APO-1 or CD 95) and its ligand (FasL, CD 95L) are cell surface proteins of the TNF receptor/ligand superfamily. After ligation of Fas with FasL, programmed cell death (apoptosis) occurs (Nagata and Golstein, 1995; Itoh et al, 1991). Monoclonal anti-Fas antibodies have been reported to induce apoptosis in many cell lines (Nakajima et al, 1995, Matsue et al, 1995; Ni et al, 1994; Ohsako et al, 1994).
It has been postulated that Fas-mediated apoptosis may play an important role in the development of autoimmunity (Baixeras et al, 1994; Cohen and Duke, 1992). Fas may also be involved in the pathogenesis of a number of human autoimmune connective tissue disorders, including systemic lupus erythematosus (SLE, Mysler et al, 1994; Emlen et al, 1994), rheumatoid arthritis (Rose et al, 1994) Hashimoto's thyroiditis (Tanimoto et al, 1995; Giordano et al, 1997) and Sjögren's syndrome (SS, Ogawa et al, 1996; Kong et al, 1997). SS is an autoimmune disorder characterized by oral and ocular dryness, diminished salivary and lacrimal function, and loss of exocrine parenchymal tissues with replacement by an active mononuclear infiltrate (Fox and Kang, 1992). The mechanisms leading to the tissue changes seen in SS are not fully understood. Recently, Fas receptor has been identified on salivary epithelial cells in human labial minor salivary glands of SS patients (Jonsson et al, 1994; Kong et al, 1997); leading to speculation that this cell surface receptor may be involved in the immunopathogenesis of this disorder.

Fas receptor may play a role in the pathogenesis of SS in a number of ways. As an example, reduced apoptosis, brought about by defects of the Fas receptor, could result in the accumulation of autoreactive T-cells in the exocrine glands, as is proposed in the MRL/lpr mouse (WatanabeFukunaga et al, 1992; Singer et al, 1994). Alternatively, Fas-mediated apoptosis within the salivary gland environment could be a mechanism leading to the loss of epithelial secretory cells via a mechanism of 'cellular suicide' (Williams, 1997). In the present study, we have used in situ immunohistochemical staining to detect Fas and FasL on sections from salivary glands of SS patients. Since animal models for SS are imperfect (Mountz and Gause, 1993), a well-characterized human submandibular gland cell line, termed HSG, was studied for the ability to undergo Fas-mediated apoptosis and for upregulation of the Fas receptor by cytokines, which have been identified at the site of tissue involvement in autoimmune disorders.

\section{Results \\ Demonstration of Fas and FasL on human labial minor salivary glands}

Figure 1 demonstrates the presence of Fas and FasL on a minor salivary gland from a SS patient. Figure $1 \mathrm{~A}$ shows staining with a rabbit polyclonal anti-Fas $\mathrm{Ab}$. Prominent staining of ducts $(\Downarrow)$ and lymphocytes $(\leftarrow)$ was seen, with less intense staining of the acini $\left(^{*}\right)$. Use of the murine monoclonal $\mathrm{Ab}$, in place of the polyclonal $\mathrm{Ab}$, produced similar staining patterns. Figure $1 \mathrm{~B}$ is the same section reacted with 
anti-FasL. The pattern of staining was similar to that seen with the anti-Fas $\mathrm{Ab}$. Figure $1 \mathrm{C}$ demonstrates the slight background staining when reacting the section with non-specific rabbit lgG Ab. Pre-incubation of the polyclonal Ab with Fas peptide prior to application on the section resulted in complete elimination of reactivity. Figure $1 \mathrm{D}$ and $\mathrm{E}$ are sections of minor gland tissue from a healthy control reacted with the anti-Fas and anti-FasL $\mathrm{Ab}$, respectively. A similar pattern of staining was found as with the SS samples. All minor glands tested had similar staining patterns for Fas and FasL, including the healthy control tissues.
A

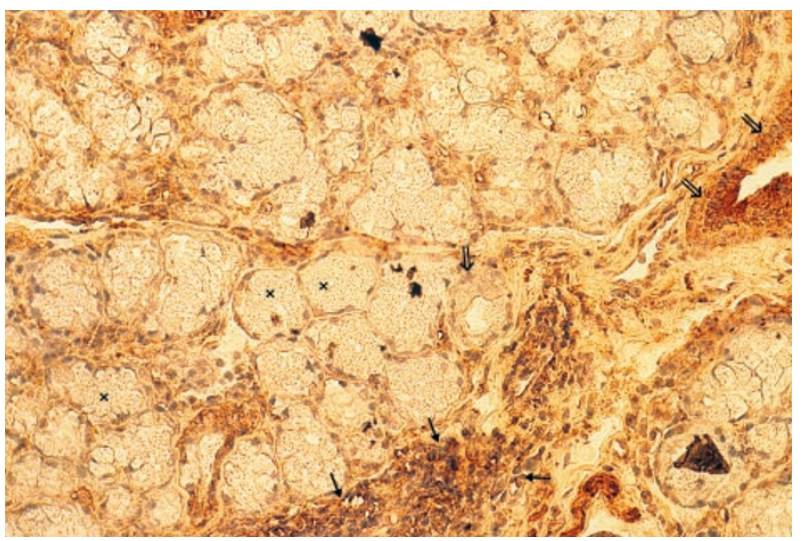

C

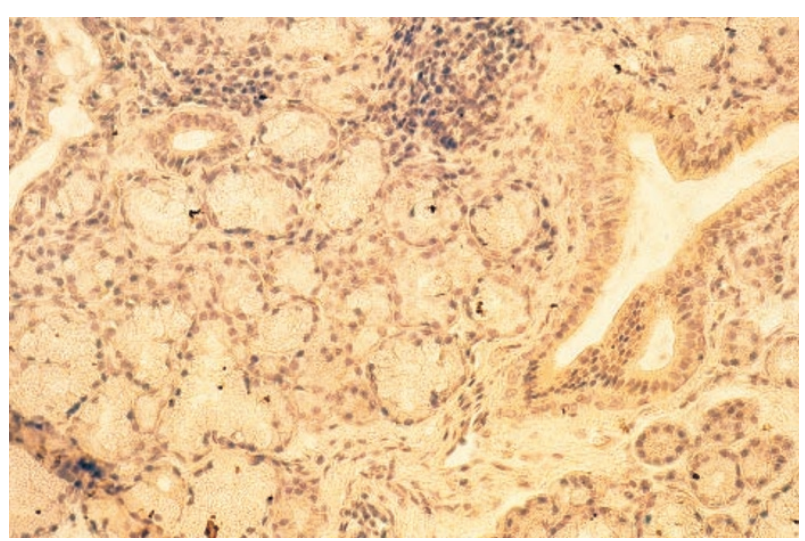

B

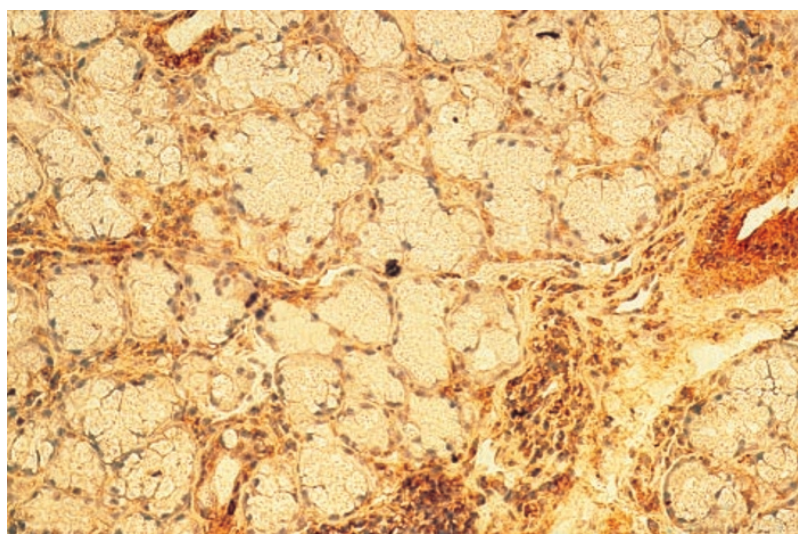

D

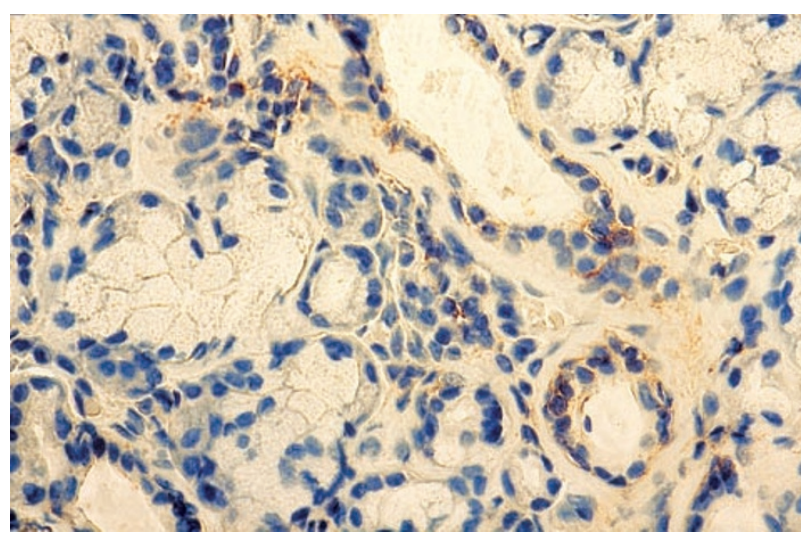

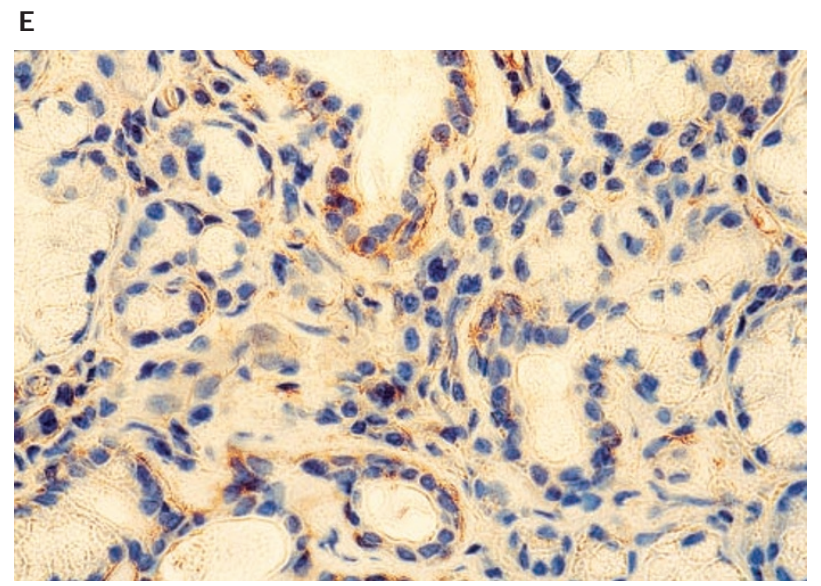

Figure 1 Histochemical staining of minor salivary gland sections from a SS patient (A-C) and a healthy control (D-E). (A) represents staining after treating the section with a rabbit polyclonal anti-Fas Ab. The *symbols mark acinar cells, the single arrows $(\leftarrow)$ infiltrating lymphocytes, and the double arrows $(\Downarrow)$ point to ducts. In (B) the section was reacted with a polyclonal anti-FasL $A b .(C)$ is a section from the same specimen stained with a control polyclonal rabbit IgG Ab to demonstrate non-specific background reactivity. (D) is a section from a healthy control gland reacted with anti-Fas $A b$ and $(E)$ was reacted with anti-FasL Ab. The overall staining intensity (mean of three examiners) for these sections was $(\mathbf{A})$ lymphocytes $=4$, ducts $=2$, acini $=4.3 ;(B)$ lymphocytes $=4.3$, ducts $=2$, acini $=5$; (D) lymphocytes $=0.5$, ducts $=0$, acini $=0.6$; and $(E)$ lymphocytes $=0.6$, ducts $=1$, acini $=1$ 


\section{A comparison between the Fas and FasL staining in SS patients and healthy volunteers}

The bar graphs shown in Figure 2 represent the mean Fas and FasL staining intensity for ducts, acini and lymphocytes from minor salivary glands of SS patients compared to healthy glands. There was increased staining of each of the glandular elements in the SS minor glands compared to the control tissues. Control minor glands from healthy individuals had scattered lymphocytes in the tissue, but lacked the focal infiltration characteristic of SS found in the patient specimens. The intensity of the lymphocyte staining in the control tissues was less than in the patient samples. There was a strong positive correlation between the intensity of Fas and FasL staining $(P=0.0005)$ for the individual sections examined. Correlations of staining intensity with clinical disease parameters demonstrated a positive correlation with a serological indicator of disease activity (serum $\operatorname{lgG}, P=0.009$ ), but not with intensity of gland inflammatory involvement (focus scores).

\section{Demonstration of Fas receptor on HSG cells and modulation of Fas expression by IFN- $\gamma$}

HSG cells are a well-characterized human submandibular cell line most closely resembling intercalated ducts. Fas could be
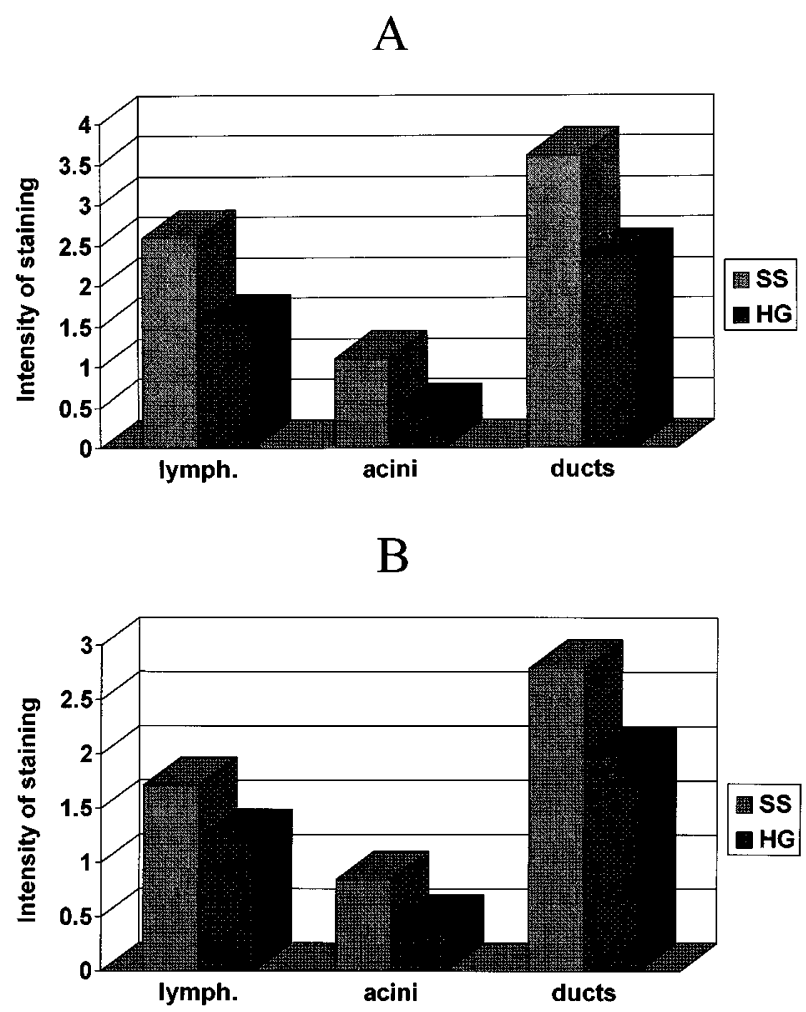

Figure 2 Mean staining intensity for all sections of $\mathrm{SS}(\mathrm{N}=$ ten patients) and healthy ( $\mathrm{N}=$ seven subjects) labial minor salivary glands $(\mathbf{A})$ represents staining intensity for $\mathrm{Fas}$ reacted with the polyclonal rabbit $\mathbf{A b}$, and (B) shows the staining intensity for FasL identified on HSG cells by FACScan analysis. Figure $3 \mathrm{~A}$ demonstrates Fas receptor expression (shaded peak) of HSG cells grown in media alone. Figure $3 B$ demonstrates the increase in Fas receptor expression following 3 days treatment of the HSG cells with 1000 units/mL IFN- $\gamma$.

\section{Effects of anti-Fas on the growth of HSG cells}

Addition of anti-Fas Ab to HSG cells resulted in a dosedependent reduction in cell growth at 3 days (Figure 4A). Doses of $0.01,0.5$, and $1.0 \mu \mathrm{g} / \mathrm{mL}$ had significant inhibitory effects compared to control media. At 3 days, cell growth was reduced by approximately $35 \%$ at the higher doses and for subsequent experiments a dose of $0.5 \mu \mathrm{g} / \mathrm{mL}$ was used. When cells were incubated for 6 days with this concentration of anti-Fas, the cell number was reduced by almost $70 \%$ (Figure 4B).

Cells were examined by FACScan for the presence of DNA fragmentation after 3 days of treatment with $0.5 \mu \mathrm{g} / \mathrm{mL}$ anti-Fas (Figure 5). Compared to the cells cultured with a control mouse IgM antisera $(9.3 \%$ Figure $5 \mathrm{~A})$ or media alone (11.3\% Figure $5 \mathrm{~B})$, there was a significant increase in the percentage of cells exhibiting subdiploid DNA, consistent with apoptotic cell death, in the anti-Fas-treated cells $(25.1 \%$ Figure $5 \mathrm{C})$.

The presence of internuclosomal DNA fragmentation was confirmed by TBE polyacrylamide gel electrophoresis of DNA extracted from control and anti-Fas treated cells (Figure 6). Cells grown for 6 days with $0.5 \mu \mathrm{g} / \mathrm{mL}$ anti-Fas (lanes 2 and 4) demonstrated a ladder pattern, characteristic of apoptosis, while control cells (lanes 3 and 5) did not. Similar results could be demonstrated at 3 days, as well (data not shown).

\section{Effects of IFN- $\gamma$ and anti-Fas, combined treatment, on the growth of HSG cells}

HSG cells were grown with IFN- $\gamma$ for 3 days. The media was changed and the final 3 days of culture were in the presence
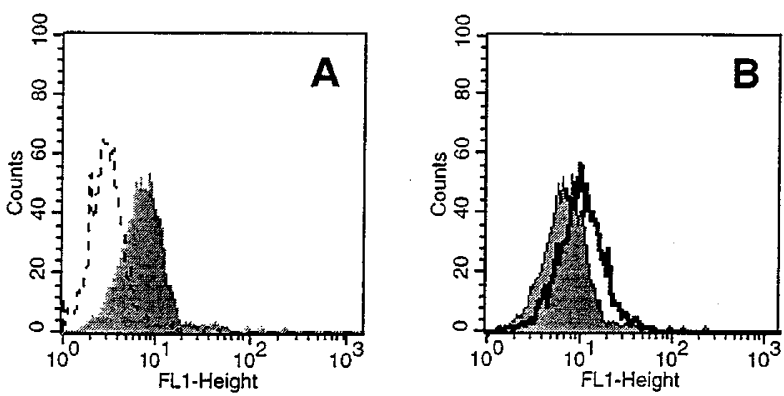

Figure 3 Expression of Fas receptor by HSG cells. In (A) cells were grown for 3 days in media and then reacted with mouse $\operatorname{lgM}(2.5 \mu \mathrm{g} / \mathrm{ml}$, dashed line) or anti-human Fas antibody $(2.5 \mu \mathrm{g} / \mathrm{ml}$, shaded peak). In (B) cells were grown for 3 days in IFN- $\gamma(1000 \mathrm{U} / \mathrm{ml})$ and then exposed to anti-Fas antibody $(2.5 \mu \mathrm{g}$ $\mathrm{ml}$, solid line). Cells were then reacted with FITC-labeled anti-mouse immunoglobulin antibody and examined by FACScan. The shaded peak in (B) represents the fluorescence for cells grown in media alone and reacted with anti-Fas antibody (as in $\mathbf{A}$ ). The results shown are representative of experiments done at least three times 


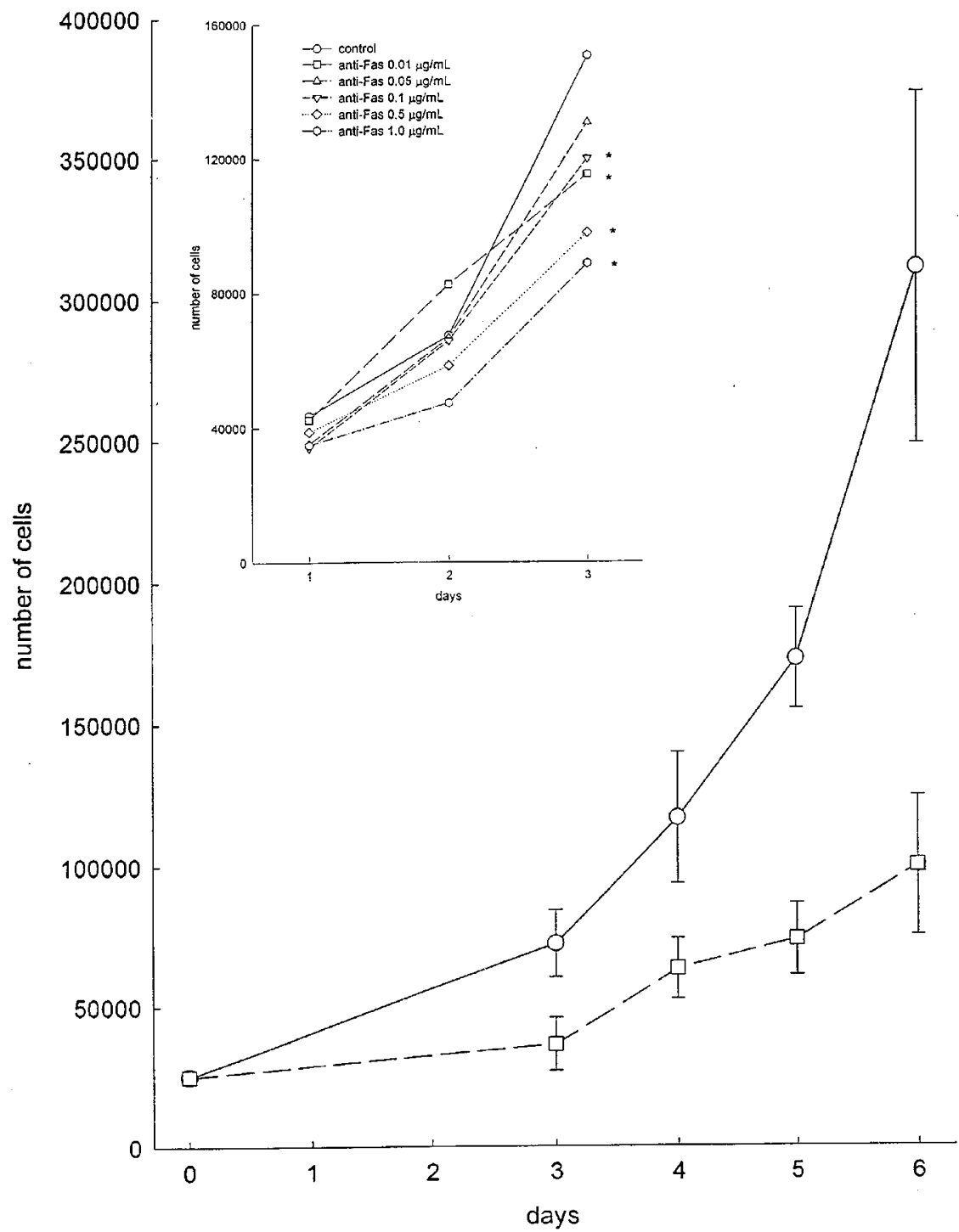

Figure 4 Time dependent growth inhibition of HSG cells by anti-human Fas antibody. (A) Cells were grown with various concentrations of anti-human Fas (0$1.0 \mu \mathrm{g} / \mathrm{ml}$ ), as indicated (Inset), for 3 days and numbers of surviving cells determined. Data are the mean of three experiments each done in triplicate. Standard errors ranged from 6 to 34 per cent. *indicates values significantly less than the control (no anti-Fas added). In (B), cells were grown for 6 days in media (O) or in media containing $0.5 \mu \mathrm{g} / \mathrm{ml}$ anti-Fas $(\square)$. The number of surviving cells were determined at the indicated time points. Data are the mean ( \pm S.E.M.) of three experiments each done in triplicate. There were significant differences between the values at day $5(P=0.01)$ and day $6(P=0.007)$

of either control media (no further IFN- $\gamma$ was added) or $0.5 \mu \mathrm{g} /$ $\mathrm{mL}$ anti-Fas. Control cells were grown in media alone for 3 days and then fresh media or anti-Fas was added for the next 3 days. As shown previously (Wu et al, 1994), the IFN- $\gamma$ treated cells initially were growth arrested, but began to grow after removal of the cytokine. However, with addition of antiFas, there was a rapid and significant further reduction in cell number in the IFN- $\gamma$ pre-treated cells. Cell number was reduced within $24 \mathrm{~h}$ and the cells remained in profound growth arrest for the remainder of the culture period (Figure 7). Addition of anti-Fas to the control cells resulted in a slowing of cell growth but not the rapid cell death seen in the IFN- $\gamma$ treated cells. Significant differences were found at day 6 between each of the treatment groups and the control. There were also significant differences between the groups treated with anti-Fas and IFN- $\gamma+$ anti-Fas $(p<0.0001)$ and between the IFN- $\gamma$ and IFN- $\gamma+$ anti-Fas-treated groups $(P<0.0001)$.

In order to demonstrate that reduced cell numbers found following anti-Fas treatment of IFN- $\gamma$-treated cells were, in fact, induced by Fas/FasL interactions, a competitive inhibitor of Fas/Fas ligand interactions, rhAPO-1/Fas : FcIgG (FasFc), was used. Cells were grown in media (Figure $8 \mathrm{~A}$ ) or IFN- $\gamma$ (Figure $8 \mathrm{~B}$ ) for 4 days. Fresh media was added and cells were grown for an additional $36 \mathrm{~h}$ in the presence of media alone, media $+0.5 \mu \mathrm{g} / \mathrm{mL}$ anti-Fas, or media + $0.5 \mu \mathrm{g} / \mathrm{mL}$ anti-Fas $+5 \mu \mathrm{g} / \mathrm{mL}$ FasFc. As shown above, in 
control cells (Figure $8 \mathrm{~A}$ ), addition of $0.5 \mu \mathrm{g} / \mathrm{mL}$ anti-Fas induced a modest but significant $(p<0.005)$ reduction in cell number. When FasFc was added with the anti-Fas antibody, there was no reduction in cell number and no significant differences compared to the control. When cells were grown first in the presence of IFN- $\gamma$ (Figure 8B), there was a more pronounced effect of the anti-Fas antibody on survival ( $>80 \%$ reduction in cell number, $p<0.001$ ), as shown earlier. When $5 \mu \mathrm{g} / \mathrm{mL}$ FasFc was added with the anti-Fas, there was still a significant decrease in cell number $\cong 50 \%$ reduction, $p<0.005)$, however, cell survival was significantly greater in the anti-Fas+FasFc-treated group compared to anti-Fas alone $(P<0.001)$.

\section{Discussion}

Fas receptor has been reported previously to be present in healthy oral gingival tissues (Yoshioka et al, 1996) and is felt to be part of a normal cell turnover mechanism. Fas and FasL have also been recognized in SS (Jonsson et al, 1994; Kong et al, 1997). In the present study, labial minor salivary glands from healthy individuals and SS patients were found to express Fas and FasL. However, salivary gland tissues from SS patients had increased intensity of staining compared to the control tissue. This upregulation of Fas and FasL suggests that increased Fas-mediated apoptosis could be a means by which salivary epithelial cells in SS are lost. Although the loss of secretory epithelial cells in SS is well described, the precise mechanism leading to this loss is not known. The increase in Fas and its ligand on the epithelial cells in the SS patients could lead to killing of the functional parenchyma, loss of secretory function, and the subsequent symptoms of oral dryness and salivary gland dysfunction.

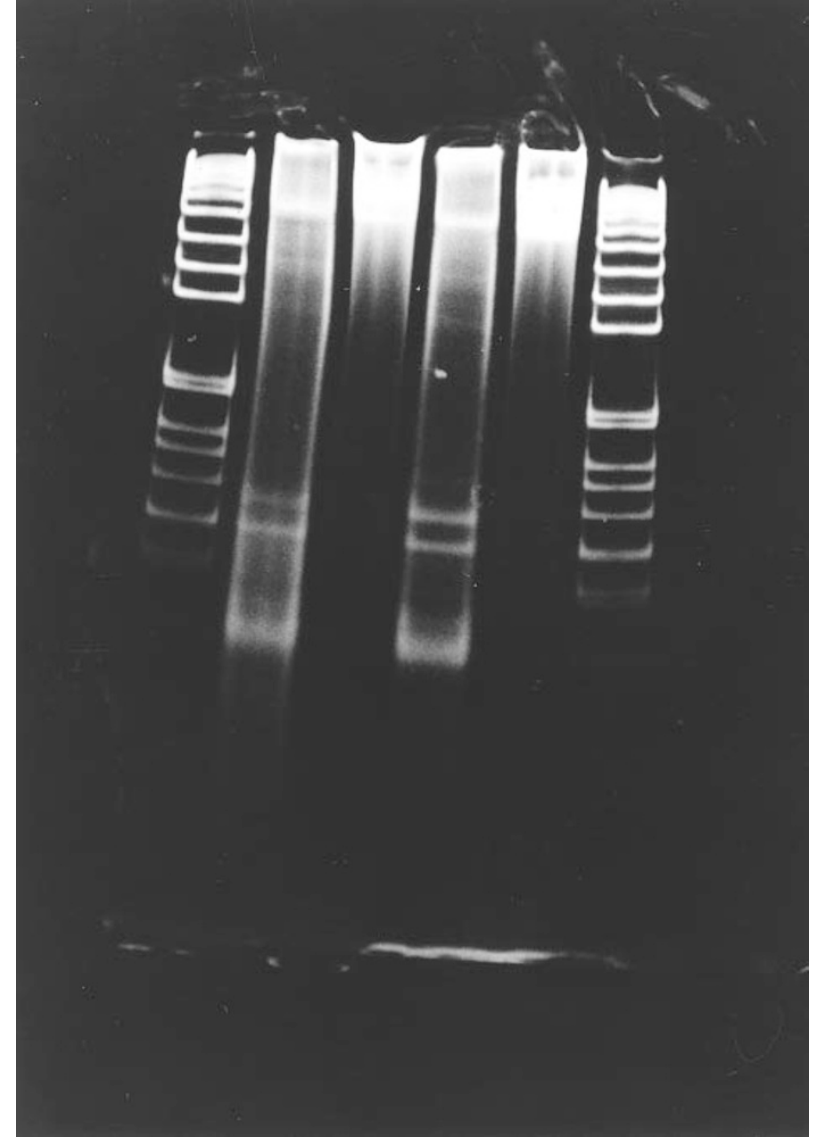

Figure $6 \quad 4-20 \%$ TBE polyacrylamide gel electrophoresis of DNA extracted from HSG cells grown for 6 days with $0.5 \mu \mathrm{g} / \mathrm{mL}$ anti-Fas antibody (lanes 2 and 4) or under normal conditions (lanes 3 and 5). Lanes 1 and 6 are a 1 kilobase DNA ladder standard. The gel was stained with ethidium bromide
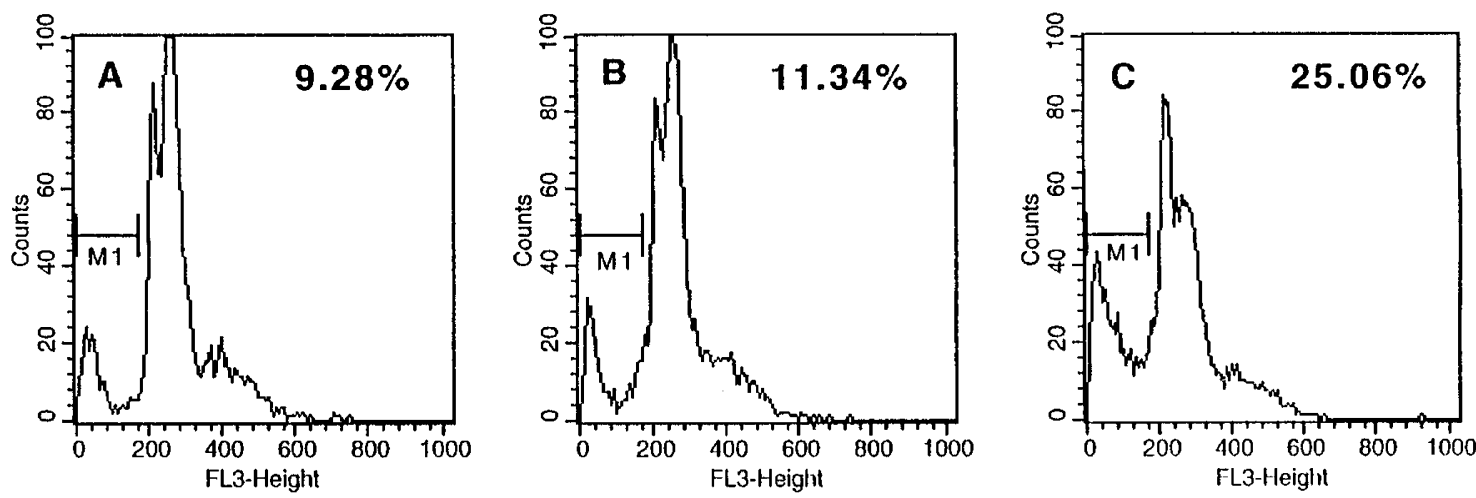

\section{DNA Content}

Figure 5 Cell death and DNA integrity in anti-human Fas-treated HSG cells. The cells were grown for 3 days in media $+\operatorname{lgM}(\mathbf{A})$, media alone (B), or media + antihuman Fas antibody $(0.5 \mu \mathrm{g} / \mathrm{ml}, \mathbf{C})$. The presence of nuclear fragmentation was determined by FACScan analysis following propidium iodide staining, as described. The percentage of cells with subdiploid DNA (indicated by the bar labeled 'M') increased in the anti-Fas-treated cells to $25.1 \%$, compared to the media (11.3\%) and the IgM-treated groups (9.3\%). These data are representative of experiments done at least three times 


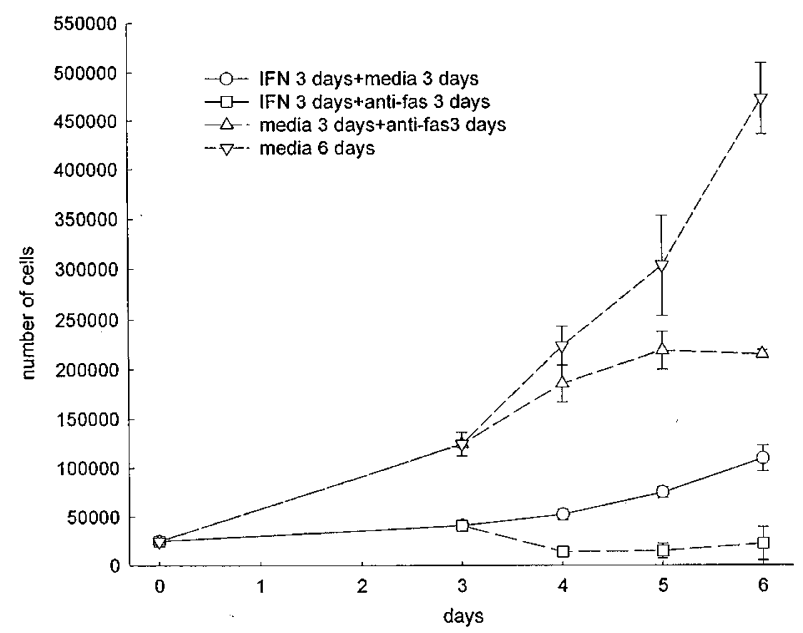

Figure 7 Anti-human Fas antibody-mediated effects on IFN- $\gamma$-treated HSG cells. Cells were treated for 3 days with IFN- $\gamma, 1000 \mathrm{U} / \mathrm{ml}$, or were grown in media alone. For the final 3 days, cells were grown with either media or anti-human Fas antibody, $0.5 \mu \mathrm{g} / \mathrm{ml}$. IFN- $\gamma$ was not present during this fina culture period. Data are the mean ( + S.E.M.) of three experiments each done in triplicate. At day 6 , there were significant differences between each of the treatment groups and the control. There were also significant differences between the media + anti-Fas and the IFN- $\gamma+$ anti-Fas groups $(P<0.0001)$ and between the IFN $-\gamma+$ media and IFN- $\gamma+$ anti-Fas groups $(P<0.0001)$

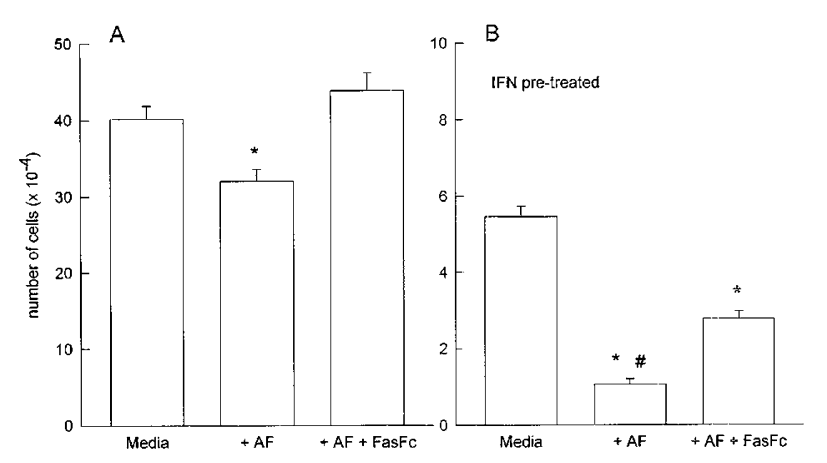

Figure 8 Inhibition of anti-human Fas antibody-mediated effects on IFN- $\gamma$ treated HSG cells with rhAPO-1/Fas: Fc-IgG (FasFc). Cells were treated for 4 days with IFN- $\gamma(\mathbf{B}), 1000 \mathrm{U} / \mathrm{ml}$, or were grown in media alone $(\mathbf{A})$. For the next $36 \mathrm{~h}$, in both $\mathbf{A}$ and $\mathbf{B}$, cells were grown with either media alone (column 1); anti-human Fas antibody (AF), $0.5 \mu \mathrm{g} / \mathrm{ml}$ (column 2); or AF+FasFc, $5 \mu \mathrm{g} / \mathrm{m}$ (column 3). IFN- $\gamma$ was not present during this final culture period. Data are the mean $( \pm$ S.E.M.) of three experiments each done in quadruplicate. *denotes a significant reduction in cell number compared to cells grown in media alone. In the IFN- $\gamma$-treated HSG cells (B), \# denotes a significant reduction in cell number of the AF group compared to the AF + FasFc-treated cells

To examine the possible effects of Fas-FasL interactions of salivary tissues, we used HSG cells which demonstrate many functional responses common to salivary epithelial cells (e.g. He et al, 1989; Royce et al, 1993) and have been shown to both produce and be responsive to cytokines (Shirasuna et al, 1981; Katz et al, 1994). Results of studies with the HSG cell line may by illuminating of the mechanisms of exocrine tissue damage in SS. We found that HSG cells express Fas and that anti-Fas Ab can induce HSG cell death.

The percentage of cell death induced by anti-Fas varies greatly depending on the cell population (Nakajima et al, 1995; Matsue et al, 1995; Ni et al, 1994; Baixeras et al, 1994; Ju et al, 1995). Typically, lymphoid cell death exceeds $90 \%$ within $24 \mathrm{~h}$, although this is partly dependent on the antibody ligand used (Ju et al, 1995). Epithelial cells demonstrate markedly slower death kinetics and the killing is substantially less (Matsue et al, 1995). Results were similar in our study. However, by extending the period of exposure of the HSG cells to anti-Fas Ab to 6 days, we achieved a reduction in cell number of approximately $70 \%$ (Figure 3).

Exposure of cells, including epithelial cell lines, to IFN- $\gamma$ has been shown to increase anti-Fas-mediated apoptosis (Nakajima et al, 1995; Ni et al, 1994; Baixeras et al, 1994; Firestein et al, 1995). We found similar effects of IFN- $\gamma$ treatment of HSG cells in the present study. We also noted a significant increase in the effects of anti-Fas antibody on HSG cells either pre-treated (Figure 7) or incubated concomitantly with IFN- $\gamma$ (data not shown). This is relevant to the clinical state in SS, since IFN- $\gamma$ has been shown to be present in the salivary environment in SS (Fox et al, 1994) and thus may be involved in the upregulation of Fas on epithelial cells in vivo.

The present studies demonstrate that HSG death observed with anti-Fas treatment is due, at least in part, to apoptotic mechanisms. The increase in $<2 \mathrm{n}$ DNA seen (Figure 5) following anti-Fas treatment is consistent with apoptotic cell death and the appearance of a DNA 'ladder' (Figure 6), considered the biochemical hallmark of apoptosis, following anti-Fas treatment provides evidence for apoptotic cell death in this cell line.

Further evidence that the cell death observed is induced by anti-Fas is provided by the experiments utilizing FasFc. This recombinant molecule, composed of the extracellular domain of human Fas fused to the Fc portion of human IgG1, has been shown to inhibit Fasmediated apoptosis competitively (Alderson et al, 1995). We found (Figure 8) that addition of this compound with anti-Fas blocked cell death of the control cells and significantly increased cell survival in the IFN- $\gamma$-treated cells, which exhibit increased Fas expression. In the latter experiments, inhibition of cell death was significant but was not complete. We speculate that higher concentrations of FasFc might lead to greater inhibition of anti-Fasinduced cell death. It is also possible that the observed cell death in the IFN- $\gamma$-treated cells is due, in part, to other than Fas-mediated interactions.

Recent reports have stressed the role of Fas in other autoimmune conditions, including Type I diabetes (Chervonsky et al, 1997) and Hashimoto's thyroiditis (Giordano et al, 1997). FasL has also been suggested to play an esential role in development of hepatitis (Kondo et al, 1997). The increased expression of both Fas and FasL in the salivary glands of SS patients argues for a substantial role for these molecules in this disorder, as well. Specifically, this is a possible mechanism by which the epithelial secretory cells may be lost in SS. It is 
significant that the intensity of Fas expression on the acini and ducts of the SS glands did not correlate with the focus scores, a measure of the intensity of mononuclear cell infiltration in these tissues. This implies that Fas expression is not simply responding to the infiltrating cells, but is a response to the underlying systemic autoimmunity. This is supported by the finding of a strong postive correlation $(P=0.009)$ between a systemic serologic indicator of disease activity in SS (serum $\operatorname{lgG}$ ) and Fas expression on the epithelial cells.

Fas and FasL were seen on the healthy control glands, as well. In the healthy, non-autoimmune gland, Fas and FasL likely are active in normal cell turnover. In SS, we hypothesize that IFN- $\gamma$ (and potentially other cytokines) in the salivary microenvironment induces upregulation of epithelial Fas and FasL, thereby increasing apoptotic cell death and leading to loss of exocrine function. Testing of this hypothesis in cell culture and animal model systems may suggest new therapeutic approaches for this inadequately treated condition.

\section{Materials and Methods}

\section{Immunohistochemical staining}

Minor salivary glands were obtained from SS patients for diagnostic purposes and from healthy volunteers (ten SS patients and seven healthy glands). Sections were formalin fixed and paraffin embedded. Sections were deparaffinized using xylene (three times $20 \mathrm{~min}$ ). The slides were stained using an AEC kit (HistoStain SP kit, Zymed, San Francisco, CA, USA) with the following first antibodies: (i) a murine monoclonal anti-Fas antibody (ZB-4 clone, Upstate Biotechnology Inc, Lake Placid, NY, USA); (ii) a rabbit polyclonal anti-Fas Ab (SC-715 clone, Santa Cruz Biotechnology, Santa Cruz, CA, USA); and (iii) a rabbit polyclonal anti-FasL Ab (SC-957, Santa Cruz Biotechnology). Controls included isotype matched Ab (Mouse IgG1, Sigma Immuno Chemicals, St. Louis, MO, USA and normal rabbit IgG, Santa Cruz Biotechnology). Binding specificity was demonstrated also by blocking experiments where polyclonal $\mathrm{Ab}$ (SC-715) was incubated for $1 \mathrm{~h}$ with Fas peptide (Santa Cruz Biotechnology) prior to application on the tissue sections.

The staining of ducts, acini, and mononuclear infiltrating cells (if present) was evaluated by three independent observers in a blinded method on a scale of $0-5$ ( $0=$ no staining; $5=$ maximum staining). The results were summarized and expressed as the mean staining intensity for each specimen. Staining intensity was correlated with a number of clinical disease parameters in the SS patients.

\section{Cell line and culture conditions}

HSG cells, a generous gift of Dr. Mitsunobu Sato of Tokushima University, Japan, were cultured in Eagle's minimal essential medium (EMEM) (Biofluids, Rockville, MD, USA) supplemented with $10 \%$ fetal calf serum (Biofluids), $2 \mathrm{mM} \mathrm{L-glutamine,} 1000$ units/ml penicillin and $100 \mu \mathrm{g} / \mathrm{ml}$ streptomycin at $37^{\circ} \mathrm{C}$ with $5 \% \mathrm{CO}_{2}$. For each experiment, confluent cells were dissociated with trypsin (NIH Media Unit, Bethesda, MD, USA) washed once with phosphate-buffered saline, (PBS, pH 7.4, Quality Biological, Inc., Gaithersburg, MD, USA) and 25000 cells per well were placed into 12-well tissue culture plates (Becton-Dickinson, Lincoln Park, NJ, USA). After $24 \mathrm{~h}$, fresh media and the various additions, as noted, were added to the cultures.
Thereafter, media and additions were changed every 3 days for all experiments. Cell number was assessed using a hemocytometer with the $0.4 \%$ trypan blue exclusion technique. All experiments were performed in triplicate.

\section{Treatment of cells with anti-Fas and FasFc}

Cells were cultured in the presence of $0.5 \mu \mathrm{g} / \mathrm{ml}$ of anti-human Fas (mouse monoclonal IgM, clone $\mathrm{CH}-11$, Upstate Biotechnology Inc., Lake Placid, NY, USA) which recognizes human cell surface Fas. The above concentration was established after several growth inhibition experiments. Cell numbers were measured daily up to 6 days employing the method described above. A mouse IgM antiserum was used as an isotype control. In certain experiments, the anti-human Fas antibody was added in the presence of $5 \mu \mathrm{g} / \mathrm{mL}$ recombinant human APO-1/ Fas : Fc-IgG (FasFc, Alexis Corp., San Diego, CA, USA), which will competitively inhibit the activity of human and mouse APO-1/Fas ligand.

\section{Treatment of cells with IFN- $\gamma$}

HSG cells were plated as described above. After $24 \mathrm{~h}$, the media was changed and 1000 units/ml IFN- $\gamma$ (recombinant human IFN- $\gamma$. Biosource International, Camarillo, CA, USA) were added based on previously reported dose response studies (Wu et al, 1994).

\section{FACS analysis for the presence of Fas receptor}

$5 \times 10^{6}$ cells $/ 10 \mathrm{ml}$ were plated on $100 \times 20 \mathrm{~mm}$ tissue culture dishes (Becton Dickinson, San Jose, CA, USA) and grown for 3 days with $1000 \mathrm{U} / \mathrm{ml}$ IFN- $\gamma$ or media alone. Cells were harvested with trypsin, centrifuged at 1000 r.p.m. for $5 \mathrm{~min}$ and re-suspended in PBS containing $1 \%$ bovine serum albumin (BSA, Sigma). The cells were treated with anti-human Fas $(2.5 \mu \mathrm{g} / \mathrm{ml})$ followed by staining with fluorescein (FITC)-labeled anti-mouse immunoglobulins antibody. Data were collected on a FACScan flow cytometer using CELL FIT software (Becton Dickinson).

\section{FACS analysis for the presence of $<\mathbf{2} n$ DNA}

Untreated cells and cells treated with anti-human Fas or mouse $\operatorname{lgM}$ were plated on tissue culture dishes $\left(5 \times 10^{6}\right.$ cells $\left./ 10 \mathrm{ml}\right)$ for 3 days. Cells were harvested with trypsin, centrifuged at 1000 r.p.m. for 5 min and suspended in PBS containing 1\% BSA. Cells were stained with propidium iodide (cycle test plus DNA kit, Becton-Dickinson) and examined with the FACScan flow cytometer.

\section{DNA extraction and acrylamide gel electrophoresis}

Untreated cells and cells treated with anti-human Fas $(0.5 \mu \mathrm{g} / \mathrm{ml})$ were plated on tissue culture dishes $\left(5 \times 10^{6}\right.$ cells $\left./ 10 \mathrm{ml}\right)$ for 6 days. Floating and adherent cells were collected by trypsinization. Cells were washed three times in $10 \mathrm{ml}$ PBS at room temperature and the cell pellets stored at $-70^{\circ} \mathrm{C}$. Genomic DNA (gDNA) was extracted using a DNA Extraction Kit (Stratagene, La Jolla, CA, USA) according to the manufacturer's recommendations. Electrophoresis of RNAse-treated gDNA (10 $\mu \mathrm{g} /$ lane) was carried out on $4-20 \%$ TBE.

\section{Statistical methods}

Data were analyzed first by one way repeated measures analysis of variance. Significant differences were resolved by Dunnett's pairwise 
multiple comparison procedure or individual $t$-tests. An $\alpha$ level of 0.05 was considered significant. Correlations between SS disease variables and intensity of Fas and FasL staining were done with Pearson and Spearman correlations.

\section{Acknowledgements}

The authors thank Dr. ZJ Chen for his assistance with the FACScan analyses and Dr. Bruce J Baum for his suggestions and careful review of the manuscript.

\section{References}

Alderson MR, Tough TW, Davis-Smith T, Braddy S, Falk B, Schooley KA, Goodwin RG, Smith CA, Ramsdell F and Lynch DH (1995) Fas ligand mediates activationinduced cell death in human T lymphocytes. J. Exp. Med. 181: 71-77

Baixeras E, Bosca L, Stauber C, Gonzalez A, Carrera AC, Gonzalo JA and MartinezAC (1994) From apoptosis to autoimmunity: Insights from the signaling pathways leading to proliferation or to programmed cell death. Immunol. Rev. 142: 53-91

Cohen JJ and Duke RC (1992) Apoptosis and programmed cell death in immunity. Annu. Rev. Immunol. 10: 267-293

Chervonsky AV, Wang Y, Wong FS, Visintin I, Flavell RA, Janeway CA and Matis LA (1997) The role of Fas in autoimmune diabetes. Cell 89: 17-24

Emlen W, Niebur J and Kadera R (1994) Accelerated in vitro apoptosis of lymphocytes from patients with systemic lupus erythematosus. J. Immunol. 152: 3685-3692

Firestein GS, Yeo M and Zvaifler NJ (1995) Apoptosis in rheumatoid arthritis synovium. J. Clin. Invest. 96: 1631-1638

Fox Rl and Kang H (1992) Pathogenesis of Sjögren's syndrome. Rheum. Dis. Clin. North. Am. 18: 517-538

Fox RI, Kang H, Ando D, Abrams J and Pisa E (1994) Cytokine mRNA expression in salivary gland biopsies of Sjögren's syndrome. J. Immunol. 152: 5532-5539

Giordano C, Stassi G, De Maria R, Todaro M, Richiusa P, Papoff G, Ruberti G, Bagnasco M, Testi R and Galluzzo A (1997) Potential involvement of Fas and its Ligand in the pathogenesis of Hashimoto's thyroiditis. Science 275: 960-963

$\mathrm{He}$ XJ, Wu XZ, Wellner RB and Baum BJ (1989) Muscarinic receptor regulation of $\mathrm{Ca}^{2+}$ mobilization in a human salivary cell line. Pflugers Arch. 413: 505-510

Itoh N, Yonehara S, Ishii A, Yonehara M, Mizushima S, Sameshima M, Hase A, Seto Y and Nagata S (1991) The polypeptide encoded by the cDNA for human cell surface antigen Fas can mediate apoptosis. Cell 66: 233-243

Jonsson R, Halse AK, Skarstein K, Cheng J, Jacobsen H, Chr Johannessen A and Mountz JD (1994) Differential expression of apoptosis-related Fas antigen in Sjögren's syndrome. Scand. J. Immunol. 40: 705

Ju S, Panka DJ, Cui H, Ettinger R, El-Khatib M, Sherr DH, Stanger BZ and MarshakRothstein A (1995) Fas (CD 95)/FasL interactions required for programmed cell death after T-cell activation. Nature 373: 444-448

Katz J, Nagler R, Barak S, Livneh A, Baum BJ, Atkinson JC and Shemer J (1994) Cytokines modulate Interleukin- 6 production by human salivary gland cell line. Cell Immunol. 159: 211-219
Kondo T, Suda T, Fukuyama H, Adachi M and Nagata S (1997) Essential roles of the Fas ligand in the development of hepatitis. Nature Medicine 3: 409-413

Kong L, Ogawa N, Nakabayashi T, Liu GT, D'souza E, McGuff HS, Guerrero D, Talal N and Dang $\mathrm{H}$ (1997) Fas and Fas Ligand expression in the salivary glands of patients with primary Sjögren's Syndrome. Arthritis Rheum. 40: 87-97

Matsue H, Kobayashi H, Hosokawa T, Akitaya T and Ohkawara A (1995) Keratinocytes constitutively express the Fas antigen that mediates apoptosis in IFN- $\gamma$ treated cultured keratinocytes. Arch. Dermatol. Res. 287: 315-320

Mountz JD and Gause WC (1993) Murine models of autoimmune disease and Sjögren's syndrome. Curr. Opin. Rheumatol. 5: 557-569

Mysler E, Bini P, Drappa J, Ramos P, Friedman SM, Krammer PH and Elkon KB (1994) The apoptosis-1/Fas protein in human systemic lupus erythematosus. J. Clin. Invest. 93: 1029-1034

Nagata S and Golstein P (1995) The Fas death factor. Science 267: 1449-1456

Nakajima T, Aono H, Hasunuma T, Yamamoto K, Shirai T, Hirohata Kand Nishioka K (1995) Apoptosis and functional Fas antigen in rheumatoid arthritis synoviocytes. Arthritis Rheum. 38: 485-491

Ni R, Tomita Y, Matsuda K, Ichihara A, Ishimura K, Ogasawara J and Nagata S (1994) Fas-mediated apoptosis in primary cultured mouse hepatocytes. Exp. Cell Res. 215: $332-337$

Ogawa N, Dang H, Kong L, Anaya JM, Liu GT and Talal N (1996) Lymphocyte apoptosis and apoptosis-associated gene expression in Sjögren's syndrome. Arthritis Rheum. 39: 1875-1885

Ohsako S, Hara M, Harigai M, Fukasawa C and Kashiwazaki S (1994) Expression and function of Fas antigen and bcl-2 in human systemic lupus erythematosus Iymphocytes. Clin. Immunol. Immunopatho. 73: 109-114

Rose LM, Latchman DS and Isenberg DA (1994) Bcl-2 and Fas, molecules which influence apoptosis. A possible role in systemic lupus erythematosus. Autoimmunity 17: 271-278

Royce LS, Kibbey MC, Mertz P, Kleinman HKand Baum BJ (1993) Human neoplastic submandibular intercalated duct cells express an acinar phenotype when cultured on a basement membrane matrix. Differentiation 52: 247-255

Shirasuna S, Sato M and Miyazaki T (1981) A neoplastic epithelial duct cell line established from an irradiated human salivary gland. Cancer 48: 745-752

Singer GG, Carrera AC, Marshak-Rothstein A, Martinez-A C and Abbas AK (1994) Apoptosis, Fas and systemic autoimmunity: the MRL-1pr/1pr model. Curr. Opin. Immunol. 6: 913-920

Tanimoto C, Hirakawa S, Kawasaki H, Hayakawa N and Ota Z (1995) Apoptosis in thyroid diseases: histochemical study. Endocr. J. 42: 193-201

Watanabe-Fukunaga R, Brannan Cl, Copeland NG, Jenkins NA and Nagata S (1992) Lymphoproliferation disorder in mice explained by defects in Fas antigen that mediates apoptosis. Nature 356: $314-317$

Williams N (1997) Thyroid disease: A case of cell suicide? Science 275: 926

Wu AJ, Kurrasch RH, Katz J, Fox PC, Baum BJ and Atkinson JC (1994) Effect of tumor necrosis factor- $\alpha$ and interferon- $\gamma$ on the growth of a human salivary gland cell line. J. Cell Physiol. 161: 217-226

Yonehara S, Ishii A and Yonehara M (1989) A cell-killing monoclonal antibody (antiFas) to a cell surface antigen co-downregulated with the receptor of tumor necrosis factor. J. Exp. Med. 169: 1747-1756

Yoshioka C, Muraki Y, Fukuda J, Haneji T and Kobayashi N (1996) Identification of the Fas antigen in human gingiva. J. Dent. Res. 75: 1353-1357 